\title{
Gandhi, Conversion, and the Equality of Religions: More Experiments with Truth ${ }^{1}$
}

\author{
Sarah Claerhout \\ Ghent University, Research Centre Vergelijkende Cultuurwetenschap, \\ Apotheekstraat 5, B-90oo Gent, Belgium \\ sarah.claerhout@ugent.be
}

\begin{abstract}
Even though Gandhi is often cited in the debate on religious conversion in India, his viewpoints have not been systematically analyzed. One reason is that his writings present a confounding blend of concepts derived from different traditions. The article argues that this fact provides a unique entry point into Gandhi's thought. By looking for systematic patterns in his distortive use of English-language terms and ideas, the background ideas that have structured his reasoning can be traced. The conceptual distortions in Gandhi's writings are shaped by these ideas, which reflect typical Indian attitudes and modes of thought on the question of religion and conversion. Analyzing his writings in this way not only allows for an explanation of his views on religion and his antagonism to conversion, but also clarifies the widespread unease towards Christian proselytism in contemporary India.
\end{abstract}

\section{Keywords}

Gandhi, religious conversion, Indian traditions, proselytism, anti-conversion laws

1 A special word of thanks has to go to the editors and the anonymous reviewers for Numen, whose comments greatly helped to improve the argumentation of this essay. I would also like to thank the members of the research group Vergelijkende Cultuurwetenschap at Ghent University for their help and support. 


\section{Conversion in India}

Religious conversion remains one of the contentious issues that divide contemporary India. ${ }^{2}$ From the nineteenth century until today, the hostility towards proselytism has rarely been far away from the center stage of national debate (Heredia 2007; Kim 2003). Several state governments have enacted freedom of religion laws that ban certain forms of conversion to Christianity or Islam and require registration of converts. In recent years, the issue has gained international attention, with interventions by the United Nations, the U.S. Commission on International Religious Freedom, and the Pope.

Commentators often link the opposition to conversion in Indian society to the ideology of Hindu nationalism (Menon 2003; Sarkar 2007; Viswanathan 2007). However, there are major obstacles in substantiating this account one such obstacle is the role of Mohandas Karamchand Gandhi. Probably one of the most recurring sentences in today's conversion debate is Gandhi's: "If I had the power and could legislate, I should certainly stop all proselytizing" (61:46). ${ }^{3}$ While Gandhi is known for his pursuit of Hindu-Muslim unity and his respect for Christianity, he also articulated reservations against its practices of proselytization. He did not only oppose proselytization, but also expressed his incomprehension towards conversion in the sense of an individual converting from one religion to another: "I cannot understand a man changing the religion of his forefathers at the instance of another" (33:100-101). In this respect, his views seem to resonate with many moderate Indians who show varying degrees of incomprehension and unease towards "conversion" both in the transitive and the intransitive sense. ${ }^{4}$

2 There has been a lot of scholarly debate on the use of the term "conversion" and its potentially different meanings in the context of India and other non-Western societies. See especially the edited volumes Hackett 2008; Buckser and Glazier 2003; Robinson and Clarke 2003; Bryant and Lamb 1999; see also Dube 2002; Dube and Dube 2003. I have analyzed this debate extensively in an earlier co-authored essay — see Claerhout and De Roover 2008. The present paper looks at the different problematic of the relationship between "conversion" understood as a theological term and what happens to this term when it is used as a natural language category in English, which is then adopted by people from non-Western cultures who speak and write in English.

3 All references to Gandhi's work give the volume number followed by the page number. The references are to the printed collected works (1964-1994, 100 vols.).

4 Often Gandhi's claims about "conversion" contain ambiguity as to whether the term should be understood in the transitive sense of converting someone or in the intransitive sense of an individual going through a process of conversion. Part of the confusion in the Indian debate on religious conversion is caused by the mixing up of these two meanings of the term. I have 
A close reading of Gandhi's views on religion and conversion may give us an entry point to better understand the current clash on religious conversion in India. His antagonism towards conversion has long been familiar to scholars of religion; yet, his perspective on this issue has not yet been studied systematically. Given that Gandhi did recognize the freedom of the individual to change from one religion to another and that he advocated the equality of all religions, how should the fact that he also seemed to object to both proselytization and individual conversion be understood?

\section{Making Sense of Gandhi}

Interpreting Gandhi's writings is never an easy task. He said many things and used many different words to say those things. His vocabulary is often misleading. Many of his ideas are "buried in a porridge of saintly rhetoric, of 'purity of heart,' " as Akeel Bilgrami puts it (2001:55). Scholars connect Gandhi's views on religion to the particulars of his biography, especially his political life (Arnold 2001; Parekh 1997; Tidrick 2006), or they seem to take his words at face value (Seshagiri Rao 1990; Seshagiri Rao 1999; Singh and Singh 2004). Explaining the conceptual logic behind Gandhi's claims is a challenge. Though much interesting work with this focus has been done (see Bilgrami 2003; Bilgrami 2011; Chatterjee 1983; Dalton 2012; Dhareshwar 2010; Jordens 1998; Parel 2006; Skaria 2011), much more needs to be done. ${ }^{5}$

Any reader of Gandhi's writings on religion and conversion confronts the challenge of making sense of his claims. His writings consist of arguments developed over several decades and in response to various circumstances. Gandhi uses English-language terms in idiosyncratic ways and with unusual connotations. Consequently, one regularly faces prima facie inconsistencies in his claims. For instance, he says he detests conversion and fails to understand its rationale, but also declares it highly desirable. ${ }^{6}$ In one passage, Gandhi states that he regards Christianity as "equally true" with his own religion, while he just announced that he does "not accept the orthodox teaching that Jesus was or is God incarnate in the accepted sense that he was or is the only son of God" $\left(23: 85^{-86}\right)$. The implication is that the core doctrine of orthodox Christianity is false. In spite of such apparent inconsistencies, several authors note, there is

retained this ambiguity in my analysis of Gandhi's writings, except in sections where clarifying the specific sense of the term is relevant to the argument.

5 For an interesting overview of recent Gandhi scholarship, see Dalton 2012:212-221.

6 See next section for illustrative quotations. 
a deeper integrity to his thought (Bilgrami 2003; Bilgrami 2011; Chatterjee 1983; Dhareshwar 2010; Iyer 1973). I will argue that the reason why this is not clear at first sight is that Gandhi's use of English-language terms is "distortive" in a particular sense. That is, he relates notions such as religion, conversion, truth, and equality to each other in unexpected ways. The result is a specific kind of conceptual distortion. ${ }^{7}$

Let me explain what is meant by "conceptual distortion" here. My use of this term does not have any normative or pejorative connotation; "distortion" is used as a technical term. When today's scholars and their readers discuss the subject of religion in languages like English, they invoke all kinds of common ideas. For instance, they usually assume that each people or culture has some form of religion and that "belief" and "worship" are central to religion, that religions can have one God or many gods, and that this corresponds to the distinction between "monotheism" and "polytheism." Some of these commonplaces have their origin in Christian theological discourse, others in modern philosophy. Many have been elaborated into theories about religion or systematic descriptions of the different "religions" of humanity. I would like to introduce the technical term "topos" (plural "topoi") to refer to such common ideas that have been developed into theories.

Topoi are not simply isolated ideas but occur as clusters of interrelated ideas. As has been argued elsewhere, the interpretation and elaboration of all such topoi depend on the presence of other common ideas. ${ }^{8}$ That is, the topoi about religion that circulate in Western society are intelligible and productive as clusters of ideas because of a shared conceptual background, which allows us to interpret these ideas and elaborate on them. Topoi require this background to continue to function as common ideas for the culture or society in question. This does not mean that these clusters of common ideas are fixed immemorial. They change and evolve and can be interpreted and articulated in many different ways. The topoi can also be modified, combined and recombined creatively in ways that lead to conceptual change. Yet, this happens

7 Gandhi's particular use of certain words has been pointed out in different contexts and arguments by many Gandhi scholars. For instance, Akeel Bilgrami refers to this in relation to words like "reason" and "moral sense" (2011:95). Dennis Dalton also points to the differences between Western notions of political liberty and swaraj in Gandhi's understanding (2012:28). In this article, this problem is tackled by speaking in terms of "conceptual distortion."

8 These ideas on topoi were developed by S. N. Balagangadhara and are only briefly summarized here. For a more elaborate explanation, see De Roover, Claerhout, and Balagangadhara 2011:578-581. 
within certain conceptual limits, because crossing these limits would entail the loss of coherence and intelligibility for the relevant cluster of ideas.

In this essay, I would like to define "conceptual distortion" as the process that occurs when topoi originating from one cultural setting are interpreted against another cultural background - that is, by making use of topoi or common ideas from another culture. In their use of the English language, Gandhi's writings in English and the translations of his Gujarati writings invoke certain common ideas and phrases that were inherent to the idiom of his time. The focus of this essay is on Gandhi's English writings, as this is how he has primarily been read by the rest of India and the world. ${ }^{9}$ The aim of my interpretation of his claims on "religion" and "conversion" is not so much to discover the original meaning that Gandhi himself intended. Rather it is to identify those conceptual distortions in the use of English-language terms and concepts that Gandhi regularly invoked. It is my hypothesis that these conceptual distortions are caused by the background clusters of common ideas that Gandhi shared with other educated people raised in the India of his time.

Of course, these common ideas or topoi shared by groups of educated Indians were not invariant. As was the case in Europe, not all common ideas circulating in Indian society were shared by all members of that society. It is for empirical research to determine the geographical and sociological scope of certain topoi. That is, specific research projects will be needed to find out the extent to which some particular cluster of common ideas was indeed common across the educated classes of India. In the case of Gandhi's statements on "religion" and "conversion," however, we do have some indications that his peculiar use of certain terms and ideas is not purely idiosyncratic: his claims and his language use resonated with many of his contemporaries and later generations of Indians. Several passages by Gandhi are still being quoted approvingly in the contemporary debate on religious conversion in India. Take the above-mentioned example: "If I had the power and could legislate, I should certainly stop all proselytizing." Irrespectively of what Gandhi meant by this statement, the fact that it seems to resonate with so many Indians' aversion towards conversion indicates that there may be interesting links here between

9 In his introduction to the 1997 edition of Hind Swaraj, the famous Gandhi-scholar Anthony Parel makes an interesting observation about Gandhi's own translation of Hind Swaraj into English: "As such, the English text of this work ... possesses an authority all of its own. It was this text that Tolstoy and Romain Rolland, Nehru and Rajaji read and commented upon. It was through this, not the Gujarati text, that he hoped, as he put it, 'to use the British race' for transmitting his 'mighty message of ahimsa' to the rest of the world" (2009:xxv). See Skaria 2002 for the tension between reading Gandhi in English and in Gujarati. 
Gandhi's thought and certain attitudes and modes of reasoning that are fairly widespread in India.

How then can we interpret Gandhi's writings on "religion" by taking into account their conceptual distortions? Metaphorically, it helps to think in terms of two layers: at the surface, there is the layer of Gandhi's claims on religion and conversion, where he makes use not just of English-language terms and phrases, but also (through them, as it were) of Western topoi. Underneath this lies a more fundamental conceptual layer that we need to dig up, where Gandhi calls on the topoi of his own cultural traditions to make sense of these Western topoi. This second layer reflects Indian modes of reasoning about the nature of traditions, the role of reason, the meaning of truth, and changes within and between traditions. To a large extent, Gandhi's use of English-language terms is mapped onto the conceptual schemes of this deeper layer. That is, he adopts typical formulae from Christian theology and Western philosophy but in the process of interpreting these maps them onto Indian topoi.

In the surface layer, then, we face a confounding conceptual blend of East and West (Arnold 2001:13; Parel 2006:x). Nevertheless, the surface layer offers an interesting access point to the deeper layer. This is the case, because the conceptual distortion does not occur at random but in a systematic way. The systematic nature of the distortions, I propose, expresses the structure of the topoi that lie behind Gandhi's claims and interpretations of Englishlanguage terms. Furthermore, these topoi or common ideas derive from the background theories of the Indian traditions that have shaped his reasoning. Tracking such underlying ideas allows one to characterize basic structures of these traditions.

This is not the same as saying that Gandhi derived his ideas both from Western and Indian philosophy and that it therefore helps to consult the dual linguistic sources of his thought (Parel 2000:1-3). This is true, but the interpretive challenge we face goes even deeper: we have to uncover the systematic patterns in the conceptual distortion in Gandhi's use of Western topoi. Once we have circumscribed such patterns, we can begin to develop hypotheses on the underlying ideas expressed in these conceptual distortions. ${ }^{10}$

Why not move straight to Gandhi's writings in Gujarati to reconstruct this fundamental conceptual layer? It seems likely that in his Indian-language

10 This opens up a route to engage in comparative research. As Balagangadhara puts it in his Reconceptualizing India Studies: "Indians reproduce Western descriptions as Indians understand them... This addition opens up a way for us to study, too, in a comparative way. There is a pattern and systematicity to the Indian transformation of Western descriptions of other cultures, the cultural world and themselves" (2012:90). 
writings the topoi of Indian culture must be more clearly present at the surface. This might indeed be the case. But there is one element that needs to be kept in mind: at a certain point, the interpreters of Gandhi's writings in Gujarati and in English (and in any other translation for that matter) will confront similar difficulties. The problem is that most dominant ideas that we use today in the social sciences and humanities to think about "religion" are topoi that have emerged from Western-Christian history and were formulated in European languages. While translating the Gujarati texts - to English, for instance, so that we can share the insights with the scholarly community contemporary scholars and their readers will inevitably take recourse to these clusters of ideas to interpret Gandhi's thought. We may then be less aware of the distortion that we as interpreters inflict upon his thought, because we lack a vantage point to discern such distortions. In contrast, Gandhi's texts in English provide us with a vantage point that compels us to recognize the problem of conceptual distortion. Therefore, this paper explores the heuristic opportunities of this vantage point - without of course discounting the importance of reading Gandhi's writings in Gujarati in the on-going efforts to better understand his thought.

In this essay, I will analyze the "conceptual distortions" in Gandhi's writings on religious conversion in order to excavate the deeper layer of common Indian ideas about this subject. The following section reveals some specific difficulties in making sense of Gandhi's claims about "conversion" and "religion." This allows me to identify instances where topoi from one culture are interpreted against a different cultural background. In the third section, I theorize the conceptual framework that is expressed in Gandhi's distortions. This leads to new insights into the Indian topoi that shaped his thinking and helps me explain the growing opposition to conversion in modern India.

\section{What Does India Need: Tradition or Conversion?}

The issues of conversion and proselytization were central to Gandhi's thought for many decades. He writes about them in response to different contexts, but the activities of Christian missionaries draw his special attention. From the start, his writings show ambiguity towards conversion. He strongly opposes the missionaries' use of humanitarian work in order to convert people to their religion: "Will not the great missionary bodies of India, to whom she owes a deep debt of gratitude for what they have done and are doing, do still better and serve the spirit of Christianity better, by dropping the goal of proselytising but continuing their philanthropic work?" (13:219-225). According to Gandhi, 
conversion harms the Indian social fabric: it always leaves a sore behind. This is certainly the case with active proselytizing, but Gandhi also appears to have in mind cases where an individual decides to leave the tradition in which he was born in order to convert to Christianity. Conversions to Christianity, he suggests, often lead to immoral behavior and to an attitude that is un-Indian, unnational, and disrespectful of Indian traditions (28:91-93). On the other hand, Gandhi asserts that conversion entails "a life of greater dedication to one's own country, greater surrender to God, greater self-purification" (ibid.). Here, he relates conversion to a search for truth and characterizes it as "a new birth," "a change of heart," and "a definite giving up of evil." He understands the spiritual quest of Christians as an expression of this human quest for inner conversion towards a pure and moral way of life (13:219-225).

How should we account for these two apparently conflicting positions? One way of doing so is to suggest that Gandhi intends to distinguish between external proselytization through material means - of which he disapproves - and a spiritual process of true inner conversion that he encourages. This contrast is familiar from Christian intellectual traditions. Especially after the Protestant Reformation, it has played a central role in Western reasoning about religion. One of the recurring themes in the work of the Magisterial Reformers of sixteenth-century Europe was that the Christian believers of their time were only nominal Christians who had adopted the external trappings of religion but whose souls had not gone through the spiritual process of "conversion" in the sense of turning towards the true God and submitting oneself to Him. Hence, a new kind of focus came to lie on conversion as the intra-Christian process by which a believer gradually becomes a true Christian. This process of conversion or "new birth," they argued, was the core of Christian religion, which should shape the lives of all believers.

In the course of its history, Christian theology has attributed a number of defining properties to conversion. Even though the different branches and thinkers of Christian theology gave many different interpretations of conversion, a rough sketch of the outer limits within which the main theologians of the Magisterial Reformation understood this process can be given nevertheless. ${ }^{11}$ For some process to qualify as a process of conversion, certain

11 This rough sketch is based on a study of the understanding of conversion in the works of important Reformation thinkers such as Martin Luther, John Calvin, Philip Melanchthon, Martin Bucer, and Katharina Schütz Zell (see Claerhout 2010). Along with this analysis of a body of primary sources, the following selection of secondary works is helpful in understanding the nature of this process of conversion in post-Reformation Christianity: Citron 1951; Brauer 1978; Caldwell 1983; Harran 1983; Hendrix 2004; Morrison 1992; 
necessary conditions need to be fulfilled. First, it concerns a spiritual changea purification of the soul or spiritual nature of humanity but not of the sinful body. What or who is being transformed spiritually? The soul or spirit is the main object of this spiritual transformation. The core of the transformation is that one is no longer occupied with earthly matters but gets insight into the spiritual domain. This is what the phrase "new birth" signifies and this is why it is an internal Christian process (see Citron 1951). This presupposes an anthropology that divides the human being into two natures, the soul and the body. Conversion redirects our entire being from the material, this-worldly to the spiritual, other-worldly sphere. Second, conversion can start only with the help of the biblical God. By human effort alone, we cannot attain anything worthwhile spiritually. Human beings should not interfere in the lives of each other's souls. Only the faith given by God and His Word can instigate the process of conversion. Humanity depends solely on His grace to transform our hearts, minds, and lives. Third, conversion is the mechanism that restores the sight of the sinner and makes one see the inherent iniquity of our nature. This transition is the "change of heart" and "new birth." Fourth, conversion never comes to completion in this life on earth. As long as human beings are clenched to their carnal bodies, the process cannot be completely fulfilled. Finally, this process of conversion requires the structures and strictures of true religion: Scripture as the revealed word of God, and its correct interpretation. Even though the Protestant-Christian traditions are not a monolithic entity, the dominant theological interpretations of conversion in the Magisterial Reformation gave importance to these properties.

At first sight, Gandhi appears to be discussing the same process, since he invokes the terminology of "new birth" and "change of heart" (13:219-225), and suggests, "conversion is a heart-process known only to and by God" (32:515516). But it soon becomes clear that he cannot have the same thing in mind: he attributes properties to conversion that are incompatible with the above picture. First, Gandhi's "change of heart" is an achievement of the satyagrahi or "truth-seeker" as a human being, rather than a process that can be initiated and sustained only by God. He views non-violence (ahimsa) as a process of conversion that aims at reforming the satyagrahis morally and spiritually

Muldoon 1997. In recent times the theology of religions (with authors like Jacques Dupuis and John Hick) has focused on the problem of how to deal with religious pluralism in the world and its relation to (spreading) the Christian message. However, this rich literature cannot be examined here, as this is outside the scope of the concerns of this essay. Though this implies a reduction of complexity, I limit myself to sketching some general boundaries of the theology of conversion found in the central works of the Magisterial Reformation. 
(23:478). Second, it is not a process of turning away from the earthly material realm but one of transforming oneself and other people in society. The leaders of India have to go through this process of conversion in order to bring about the necessary change in others. Gandhi describes non-cooperation as a process of conversion, whereby Indians have to convert through their model conduct even the staunchest of British colonials (23:41, 30:134, 35:98-100). Third, according to him, "a new birth, a change of heart, is perfectly possible in every one of the great faiths," not just in one true religion. Ideally, conversion should take place within the tradition in which one is born and there is no concern about the truth or falsity of this tradition (13:219-225).

From this, I conclude that Gandhi is not so much talking about the distinction between true spiritual inner conversion and external proselytization by material means. At first blush, he may sound like a mainstream ProtestantChristian believer when he adopts this terminology, but he uses the terms in unexpected ways and attributes new combinations of properties to the process of conversion. Such points of divergence offer potential windows into the patterns of reasoning that gave shape to Gandhi's use of the relevant terms and phrases.

\section{Religion and Transformation}

As an entry point for understanding Gandhi's objections to conversion, take his claims about the spirit of "swadeshi" or self-sufficiency in matters of religion. According to him, Hinduism is a tradition with a powerful swadeshi spirit, and this explains why it does not proselytize: "By reason of the swadeshi spirit, a Hindu refuses to change his religion not necessarily because he considers it to be the best, but because he knows that he can complement it by introducing reforms" (ibid.). Originally, swadeshi had been an economic strategy to reduce India's dependence on British products and promote the production of Indian goods. ${ }^{12}$ Gandhi extends this notion to the religious sphere and suggests that it entails that we should limit ourselves to our ancestral religion and immediate religious surroundings. If one's religion is deemed defective, it should be purged of its defects, rather than left behind (ibid.).

He attributes this swadeshi spirit to all great "faiths" of the world including Christianity. If Christians were to understand that genuine conversion takes place within one's own tradition, they would stop investing in

12 "Swadeshi: things pertaining to one's own country." Anthony Parel clearly explains the different levels of swadeshi in a footnote in Gandhi's Hind Swaraj (2009:21). 
proselytism. Missionary activity, Gandhi suggests, sprouts from a flawed interpretation of Christianity, which understands the message "Go Ye unto All the World" narrowly and misses its spirit (ibid.). It is because Christian humanitarian work ultimately aims at converting people to Christianity that the work of the missionaries suffers (28:295-301). Instead of convincing others that some religion is superior, one should retain tradition and try to improve it, so Gandhi argues.

This shows how Gandhi's reasoning clashes with the classical understanding of conversion as the change from one religion to another, where the truth value of religious beliefs is the decisive factor, rather than their provenance. The best stance in religion is to make use of one's immediate religious surroundings, he suggests, and Christians should adopt this stance, even though — from a Christian point of view - this is equivalent to subordinating religion to the accidents of birth and geography. To draw a stark contrast: to a Calvinist convert originally born into a Roman-Catholic family, this appeal to swadeshi amounts to the claim that he should remain steeped in "false religion" and condemned to "eternal damnation," while he knows "the truth."

Gandhi repeatedly expresses his incomprehension towards practices that try to make people replace their religion with another and also to cases where individuals convert from one religion to another (33:100-101). He also objects to the practices of shuddhi that nineteenth-century Hindu reform movements had introduced in order to "re-convert" Muslims and Christians to Hinduism:

My Hindu instinct tells me that all religions are more or less true. All proceed from the same God, but all are imperfect because they have come down to us through imperfect human instrumentality. The real shuddhi movement should consist in each one trying to arrive at perfection in his or her own faith. In such a plan character would be the only test. What is the use of crossing from one compartment to another, if it does not mean a moral rise? (24:148-149)

Here, shuddhi is described as a process whereby the individual achieves a greater moral perfection "in his or her own faith" and which is incompatible with crossing from one religion to another.

There are three dimensions central to Gandhi's understanding of conversion. First, he encourages "conversion" but only as a process of moral growth within one's own tradition. This generates an important question: Is conversion between religions acceptable if there is a moral rise of the individual? Gandhi allows for this possibility but is not convinced that conversion to Christianity brings this about (30:312, 35:461-464). Abstractly speaking, the 
possibility of converting to another religion is an ever-present option to the individual. However, its reference point does not rest in the truth-value of religious teachings but in moral considerations. Conversion to another religion is justified only in so far as it makes an individual morally superior compared to before. From this perspective, Gandhi implies, it is both unnecessary and divisive, since all great religions are bearers of excellent moral guidelines and capable of internal improvement.

The second dimension is that Gandhi attributes to every individual a responsibility to transform and purify his own tradition, whenever he feels that it contains immoral elements. The prototypical case is the problem of untouchability in Hinduism. In this context, he again uses the term "conversion" in two ways: conversion to another religion as a way of escaping untouchability, and conversion as the process Hindus have to undergo to uplift their tradition by eradicating untouchability. The first, he suggests, is not a proper remedy, because "no physical inconvenience can warrant abandonment of one's own religion," and "untouchability is no part of Hinduism," but "rather its excrescence to be removed by every effort" (18:376-377). Gandhi describes the threat to abandon Hinduism as a betrayal of one's faith. A religion can survive only if its followers help eradicate its impurities. Conversion of Hinduism in the sense of removing untouchability is the task at hand. The claim that "the campaign against untouchability is not one of compulsion, but of conversion" is a recurring refrain in Gandhi's writings (52:374, 53:260-261, 293). Here Gandhi's use of "conversion" also indicates that it concerns a process where Hindus change their practices because they themselves become convinced that this should happen and not because they are forced to. But most importantly it concerns a process of internal transformation of a tradition. Without this type of "conversion," Hinduism might as well perish (62:280-281, 63:33-39). Consequently, taking recourse to conversion to another religion implies that reform within one's own religion has become impossible.

The third dimension of Gandhi's discussion of "conversion" concerns the attempt to transform other human beings. In his text Why I Am a Hindu (1927), he addresses this question when he responds to the request of an American friend to compare Hinduism with the teachings of Christ. He points out that faith is not something that can be transmitted by persuading others. Hence, it is impossible to compare Christianity with Hinduism in this way:

I have ventured at several missionary meetings to tell English and American missionaries that if they could have refrained from "telling" India about Christ and had merely lived the life enjoined upon them by the Sermon on the Mount, India instead of suspecting them would have 
appreciated their living in the midst of her children and directly profited by their presence. Holding this view, I can "tell" American friends nothing about Hinduism by way of "return." I do not believe in people telling others of their faith, especially with a view to conversion. Faith does not admit of telling. It has to be lived and then it becomes self-propagating. Nor do I consider myself fit to interpret Hinduism except through my own life. And if I may not interpret Hinduism through my written word, I may not compare it with Christianity. $(35: 166-167)^{13}$

Religion, so Gandhi stresses, does not spread by persuading others about its truth claims. The only thing that can be done is to "live" and "interpret" a religion in one's own life. In Gandhi's view, when we are able to morally transform our lives and truly embody the guidelines of our religion in our experience and action, we will automatically begin to have a moral impact on our surroundings and transform the lives of others. To put it in terms of a famous phrase often ascribed to Gandhi (but not found in his printed works): "Be the change you want to see in the world." Gandhi often turns to the metaphor of a rose. A religion spreads not by persuasion or proselytization but through the lived experiences of its followers: "It radiates its influence silently as the rose its fragrance without the intervention of medium" (40:60; see also 46:27-29, 48:121-122, 64:37).

At this level, Gandhi praises the humanitarian endeavors of Christian missionaries as an expression of how a religion is to be interpreted through the lives of its followers. Naturally, many Christians would agree that it is crucial to embody the teachings of Christ and emulate Him. However, there is a marked difference here. Christian missionaries cannot limit themselves to this alone, since they also have to evangelize, that is, to spread the message of the Gospel. Just by living in a particular way, they could never transmit the propositional content of their religion. ${ }^{14}$ From observing the behavior of the missionary alone, potential converts could never infer even the minimal core of Christian teachings: that the biblical God exists, the role of Christ, the Trinity,

13 Emphasis added.

14 There are a variety of Christian missiological theories that characterize different approaches to evangelizing and proselytization (Ustorf 2000). They range from proactively aiming to baptize as many people as possible to living a Christian life without actively trying to convert non-Christians (and waiting for them to take the initiative). However, whatever the missionary approach or theory one follows, the aim is to evangelize nonChristians. To be successful, this evangelization involves the transmission of Christian teachings or the Gospel. 
the theology of the cross, etc. Since religion here revolves (among other things) around the truth of its doctrines about God, humanity, and salvation, the missionary is compelled to transmit this by persuading others.

\section{The Question of Religious Truth}

Gandhi famously holds the view that all religions are more or less true. If all religions are more or less the same with respect to truth, this cannot provide a reason for changing from one religion to another. Gandhi formulates his view as follows in a much-quoted passage from his discussion on "fellowship" (1928):

I came to the conclusion long ago, after prayerful search and study and discussion with as many people as I could meet, that all religions were true and also that all had some error in them, and that whilst I hold by my own, I should hold others as dear as Hinduism, from which it logically follows that we should hold all as dear as our nearest kith and kin and that we should make no distinction between them. So we can only pray, if we are Hindus, not that a Christian should become a Hindu, or if we are Mussalmans, not that a Hindu or a Christian should become a Mussalman, nor should we even secretly pray that anyone should be converted, but our inmost prayer should be that a Hindu should be a better Hindu, a Muslim a better Muslim and a Christian a better Christian... If however there is any suspicion in your minds that only one religion can be true and others false, you must reject the doctrine of fellowship placed before you. $(35: 461-464)^{15}$

Given the truth of all religions, it is best to follow one's own - meaning the one in which one is born and raised - but hold others as dear and close. At first blush, this view of religious truth harbors a basic inconsistency. If all religions are true, then Christian, Islamic, and Hindu teachings should be true at the same time. This entails that one religious doctrine, which claims that each human individual has a unique soul destined for eternal salvation or damnation, should be compatible with another, which asserts that there is a "transmigration of souls" between individuals. This seems impossible.

Gandhi appears to have another conception of "truth" in mind than truth as a property of propositions, doctrines, or beliefs (see also Jordens 1987; Bilgrami 2003; Bilgrami 2011:96; Chatterjee 1983:74; Parel 2006:195-196). Indeed, he does

15 Emphasis added. 
not refer to the "truth" of doctrines: "By a true faith I mean one the sum total of whose energy is for the good of its adherents, by a false I mean that which is predominantly false" (35:461-464). Still, the above passage involves a peculiar ambiguity. When Gandhi says that he came to the conclusion that "all religions were true and also that all had some error in them," the predicate "true" cannot refer to the truth of conflicting doctrines or beliefs. But when he mentions other people's belief "that only one religion can be true and others false," he inevitably refers to the orthodox position of Christianity and Islam. In this orthodox position, "true" and "false" $d o$ also refer to the truth-value of religious doctrines.

This ambiguity about the meaning of "truth" in religion is common in Gandhi's writings. For instance, he praises Hinduism's lack of dogmatism as follows:

Its freedom from dogma makes a forcible appeal to me inasmuch as it gives the votary the largest scope for self-expression. Not being an exclusive religion, it enables the followers of that faith not merely to respect all the other religions, but it also enables them to admire and assimilate whatever may be good in the other faiths. $(35: 166-167)$

However, Gandhi proceeds by claiming that "Hinduism believes in the oneness not of merely all human life but in the oneness of all that lives" and talks about its "great belief in transmigration" (ibid.). This sounds as though Hinduism does claim truth for particular beliefs or doctrines after all.

There is a deeper conflict here. On the one hand, Gandhi's characterization of Hinduism clashes with the understanding of religions as belief systems (and related practices that express these beliefs). Such systems consist of sets of beliefs that must be minimally coherent in order to make sense. While one can imagine that a few teachings of one religion are adopted by another, the minimal requirements of consistency put limits on any such process. Gandhi, however, suggests that one faith, Hinduism, can assimilate whatever it finds good in others and shows no worries about coherence. On the other hand, he appears to reproduce the understanding of religions as belief systems, when he praises Hinduism for its belief in the oneness of all that lives, the belief in the transmigration of souls, and the belief in the law of varnashrama. If Hinduism is indeed constituted by such beliefs, Hindus cannot possibly assimilate all valuable teachings of other religions.

What we can make out of the above is that Gandhi adopts classical ways of discussing "religion" in English but then uses the terms in apparently inconsistent ways, making it difficult to decipher his views. In the mentioned discussion 
on fellowship, for instance, one of the participants raises the question as to why preaching religious doctrines is not similar to promoting theories about an economic order or advocating specific laws regarding health. Gandhi's reply goes as follows: "If there were different but good and true health laws for different communities, I should hesitate to preach some as true and some as false" (35:461-464). On the contrary:

If in matters of medicine and other natural sciences, I feel my superiority over others, a thing of which I may be legitimately conscious, and if I have love for my fellow beings, I would naturally share my knowledge with them. But things of the spirit I leave to God and thus keep the bond between fellow beings and myself pure, correct and within limits. $(36: 136-137)$

This comparison with the natural sciences both clarifies and confounds Gandhi's standpoint. The clarification lies in the suggestion that the natural sciences possess criteria to assess the cognitive superiority of one theory over another. Therefore, spreading particular theories as scientific truth across different cultures and communities can be justified. In "things of the spirit," there are no such criteria that could potentially justify spreading the exclusive doctrines of one religion.

This stance is also confounding because it depends on Gandhi's idiosyncratic uses of "religion" and "truth," which are not shared by his dialogue partners like the Christian missionaries. This becomes clear in another context, where an American missionary writes an open letter to Gandhi on the issue of conversion. The missionary points out that religious truth, like scientific truth, is by its very nature universal, and reproaches Gandhi for denying to Christians the right to share Christ with others (Kim 2003:28). Once we switch to this missionary's standpoint, how puzzling Gandhi's equivocation between different senses of "truth" is can be seen. To this missionary, there are criteria to determine which religion is universally true and, therefore, superior to other religions: Scripture is the supreme criterion, since it is the revelation of the biblical God.

This ambiguity about the meaning of "truth" lies at the heart of the chasm between Gandhi and the missionaries. According to him, their effort rests on a flawed notion of truth: "At the root of missionary effort is ... the assumption that one's own belief is true not only for oneself but for all the world; whereas the truth is that God reaches us through millions of ways not understood by us ... spiritual superiority is a dangerous thing to feel" $(36: 136-137)$. Here, the 
blending of several notions of truth creates further confusion. When a belief is true, this entails that it is true for all of humanity, even though many may not believe in its truth. The truth of, say, the belief that the earth revolves around the sun is logically independent of whatever any section of humanity believes to be the case. When the Christian missionary speaks of truth, he or she does not only mean the truth of propositions but the truth of the biblical God's revelation, which is viewed as independent from any human knowledge. The message of God's revelation is true not for one or two human beings but for all of humanity. The mutual misunderstanding surfaces again when Gandhi tells a Christian clergyman the following:

I am not interested in weaning you from Christianity and making you a Hindu, and I would not relish your designs upon me, if you had any, to convert me to Christianity! I would also dispute your claim that Christianity is the only true religion. It is also a true religion, a noble religion, and along with other religions it has contributed to raise the moral height of mankind. But it has yet to make a greater contribution. After all what are 2.000 years in the life of a religion? $(64: 398)^{16}$

According to the Christian missionary, Christianity is "the truth"; according to Gandhi, Christianity is "also true" but in a different sense. Gandhi equates truth to the nobility of a religion and its moral contributions and connects this to the age of a religion: the older it is, the greater the contribution. To Christian missionaries, the question of age is largely irrelevant: their religion is not simply a contribution to humanity but the truth for humanity. They do not just assume that their belief is true for all of humanity but take the only consistent position when a doctrine is viewed as the biblical God's revelation of His will. The Christian claim is that Christianity is the unique revelation of God to humankind. Therefore, believers identify it as true and other religions as false. According to each of the different Christian confessions, its respective doctrine is regarded as the one true revelation of God's will. The only road to salvation lies in a genuine belief in this doctrine and submission to His will. Gandhi ignores this point and fails to understand fully the Christian missionary's religion and its concept of truth.

This becomes clear when he expresses his incomprehension towards the link between the humanitarian work of Christian missionaries and their mission to convert others. Because of his different notion of "truth," Gandhi

16 Emphasis added. 
cannot see the link between the truth claims of religions like Christianity, and the fundamental moral responsibility such religions instill in their believers to preach their message to the world. "Go ye into all the World" has not been narrowly understood by the Christians, as Gandhi claims, but has shaped the Christian humanitarian work (and not vice versa). When missionaries, such as E. Stanley Jones, point out that the truth in spiritual matters needs to be told and that it is their right to spread this message by persuading others, he does not appear to grasp what they are trying to convey.

This is striking in the interesting piece "About Conversion," where Gandhi is invited to comment upon a range of Christian propositions like the following: "The Christian believes that Jesus is the fulfillment of God's revelation to mankind; that He is our Saviour, that He alone can bring the sinner to God and thus enable him to live" (61:454-458). His comments are illuminating:

The... proposition deals with the Christian belief handed to the believer from generation to generation, the truth of which thousands of Christians are never called upon to test for themselves, and rightly so. Surely it is a dangerous thing to present it to those who have been brought up with a different belief. And it would be impertinent on my part to present my untested belief to the professor of another which for all I know may be as true as mine. It is highly likely that my belief is good enough for me and his is for him. A thick woollen coat would be the right dress when living in the cold regions of the earth; a piece of loincloth would be right for another living in the equatorial regions. (Ibid.)

To Gandhi, "belief" appears to be something that is handed from generation to generation and derives its "truth" from the fact that it has been tested by previous generations of a people. Therefore, it is impertinent to impose the "beliefs" of one people on another group of people. Since "belief" has been shaped by local circumstances and the past of this particular people, presenting this "belief" to others is as absurd as telling inhabitants of the tropics that they should wear thick woolen coats because people living in the Arctic do so.

In the past, such passages in Gandhi's writings have led to the claim that he (like other Hindus) is a kind of relativist in religious matters. This would indeed be the case, if Gandhi really intended to use "belief" to refer to propositions that are true or false. In that case, saying that your "belief" may be "true" (or "good") for you but my "belief" is "true" (or "good") for me would amount to some sort of relativism. However, I would like to suggest a different reading: when Gandhi discusses "beliefs," he does not refer to propositions about the 
world that are either true or false, but rather intends to refer to the transmitted action heuristics or practical instructions handed down by a community. Such heuristics or instructions for action are indeed handed from generation to generation and accepted because they have been "tested" by earlier generations. They are not propositions about the world that are either true or false, but rather instructions that can be more or less helpful in particular contexts. In this way, Gandhi's analogy of clothing in different climates becomes a sensible one: in many cases, it is absurd to impose the action heuristics of one people onto another people with a completely different past and environment. By understanding "belief" as "transmitted action heuristic," we can make better sense of Gandhi's claims. This is another instance of his conceptual distortion of English-language terms that creates difficulties in deciphering his viewpoints.

\section{Misunderstanding Distortion}

I have now illustrated several such distortions in Gandhi's writings on religion and conversion. What do these tell us? One could conclude - as some people have - that he was an incoherent thinker: he simply made use of terms from Christian theology without understanding them very well. However, such a conclusion neglects the depth of Gandhi's struggle with these words and concepts, the originality of his contribution to understanding human traditions, and the deeper coherence and integrity of his thought.

Am I arguing that Gandhi should have studied Christian theology more thoroughly? Not at all: I do not hold the theological framework of Christianity as the standard by which other people's use of the same terms should be assessed. Neither do I attribute conceptual distortion to Gandhi's writings because his vocabulary does not correspond to that sanctioned by Christian orthodoxy. It would not be helpful, I suggest, to put up some definition of words like "conversion," "belief," and "truth" on the basis of Christian theology and subsequently show that Gandhi's use of the words is different and therefore flawed. If that were the case, one could easily object by saying that it concerns a creative Indian appropriation of these concepts.

Instead of giving a definition of words, I aim to show that "conversion," "religion," "belief," and "truth" are concepts embedded in larger clusters of common-sense ideas, where these terms are used within certain limits of coherence. When these limits are violated, it becomes very difficult to understand what a person is trying to say. This is the case because these concepts 
have not come into being and survived in a vacuum. They are part of larger clusters and networks of ideas that shape the natural language use of Western societies. In the case of "religion" and its cognates, this happens to be a set of clusters that is largely determined by Christian theology and its secularization (Balagangadhara 2005b; De Roover and Balagangadhara 2008; De Roover and Claerhout 2010).

What am I proposing then? Gandhi's claims have been labeled as incoherent. I claim that it is heuristically more fruitful to think through the apparent inconsistencies and take him very seriously as a systematic thinker. Gandhi's writings do reveal a peculiar kind of prima facie incoherence. But what if this incoherence can be explained in terms of a deeper coherence? This is where the "principle of charity" in the interpretation of thinkers has to guide us: it cannot but be assumed that Gandhi uses these concepts in a way that is coherent for him and for the many Indian readers who have resonated with his writings and insights. This is the minimal consistency our interpretations should attribute to intelligent human beings (Henderson 1993). In Gandhi's case, this means that we should look for the coherent patterns behind his inconsistent use of terms like "religion," "truth," and "belief." In other words, the background framework that has shaped his conceptual distortion of topoi from Western culture has to be reconstructed. To some extent, this framework will be determined by clusters of common ideas circulating in Indian society. In other words: the conceptual distortions may offer a window into the Indian topoi or common ideas that have structured Gandhi's reasoning. In the next section, I will systematize my findings and — cautiously and tentatively — begin this work of reconstructing the background clusters of ideas behind Gandhi's views on conversion.

\section{Gandhi's Religion?}

How could we identify the Indian topoi that give shape to the conceptual distortions in Gandhi's writings? One route is to compare his individual statements about "conversion," "belief," and "truth," and try to extract such general schemes or clusters of ideas. However, given the internal variety of Gandhi's thought, this "inductive" approach will lead to uncertain results. The conceptual distortions in his writings become heuristically fruitful, if approached as the result of the interpretation of topoi from one culture through the topoi of another. Therefore, the alternative route is to formulate a general hypothesis on the Indian topoi or commonplaces that have functioned as the conceptual 
background that determined Gandhi's interpretation of Western topoi. Which topoi did he invoke and how do they distort Western topoi? In the remaining pages, I propose such a set of hypotheses that make sense of the equivocation, incoherence, and conceptual distortion in Gandhi's writings on conversion. Naturally, these hypotheses are fallible: it may be the case that some of the common ideas that I attribute to Gandhi were not really held by him or that they will need to be refined in the future to better capture his reasoning.

First, when Gandhi speaks of "faiths" or "religions," he refers to the traditions of different groups or communities. He emphasizes that one should remain within one's own "faith" and advocates swadeshi and the role of heredity in religion, because he fundamentally views religions as the ancestral traditions of a community or group. The main characteristic of such traditions is that they are transmitted from generation to generation. One does not follow a tradition because of its teachings or the truth of its propositional content but because it has been passed on. In other words, traditions consist of ancestral practices, which are not founded in doctrines or justified by reasons. Practices do not embody beliefs that one holds to be true.

If traditions are continued because they are ancestral practices, how to account for Gandhi's emphasis on reform, purification, and the rejection of practices like untouchability? It should be clear that this notion of tradition does not entail that any practice is defended just because it was transmitted by previous generations. This is a fallacy. It is not because one has no reason to continue a body of practices that one cannot have a reason to discontinue one or several of its practices. If there are good reasons to end a practice, one should do so. This is indeed the attitude seen in Gandhi (e.g., vis-à-vis child marriage, caste practices). Bilgrami also stresses that "one may apply one's 'moral sense' and 'reason' and be selective in embracing what was given to one, as he [Gandhi] himself certainly was in his own Hinduism" (2011:103). Typical to a vibrant tradition is its potential to change in this way. One can modify any practice so as to retain its viability or reject it if the reasons against it are compelling (Chatterjee 1983:8).

This process of "purifying" a tradition from deficiencies is what Gandhi calls "conversion" in a positive sense: a process of transformation that takes place within the confines of one's own tradition. He puts a premium on its importance, because this aspect of traditions is often ignored. He also stresses the particular relationship between the individual and his or her tradition. The individual has the duty to pursue the modification or eradication of practices, when there are compelling reasons to do so. If the "faith" one belongs to is defiled by impurities, these should be transformed. This attitude is essential to 
the vibrancy of a tradition, and goes hand in hand with tenacity in continuing the tradition. This also accounts for Gandhi's surprise at conversion to another religion when people barely know their own religion. ${ }^{17}$

Second, "religion" consists of the traditions of a particular community or group of people. It is the set of ancestral practices that has constituted some community. Over time, in the process of transmission and selection, earlier generations have filtered out practices, modified or rejected them. This explains the close connection in Gandhi's thought between religious traditions and the welfare of peoples..$^{18}$ In 1931, when he was interviewed by a newspaper about the role of foreign missionaries in independent India, the report said that he would ask them to withdraw if they engaged in proselytizing by means of medical aid and education. Later that same year, Gandhi expresses his anger, because the press had twisted his words. "This is what a reporter has put into my mouth," Gandhi says: "Every nation's religion is as good as any other. Certainly India's religions are adequate for her people. We need no converting spiritually." Gandhi cannot recall saying this and retouches the statement: "Every nation considers its own faith to be as good as that of any other. Certainly the great faiths held by the people of India are adequate for her people. India stands in no need of conversion from one faith to another" (46:27-29).

The modifications are interesting. In both versions, Gandhi attributes certain characteristics to religion: religions are connected to peoples and assessed in terms of their adequacy for the needs of peoples (he does not use "nation" in the sense of nation-state here). There is no need for conversion, because each group has its own religions that have historically fulfilled its needs. Apart from softening the tone, the last sentence is crucial in Gandhi's correction. The issue is not that "we need no converting spiritually"; in fact spiritual conversion is desirable, but the issue is whether India stands in "need of conversion from one faith to another." This last sentence must have troubled Gandhi, because it equivocates between the two kinds of "conversion" he distinguishes. His entire

17 During his studies in London, friends advised him to join the Theosophical Society, but he declined saying: "with my meagre knowledge of my own religion I do not want to belong to any religious body" (Gandhi 2007:77).

18 This is not be misread as though Gandhi was supporting the agenda of Hindu nationalist groups by claiming that India was a Hindu nation, nor as a support to a one nation-one religion ideology. This would be a serious misreading of Gandhi's ideas: he opposed the two-nation theory that advocated that Hindus and Muslims each constituted a separate nation with its own religion. Religion was not the basis for Gandhi's civic nationalism (Parel 2006:35). I would like to thank an anonymous reviewer for pointing out this possible misreading in an earlier draft. 
project is a call for spiritual and moral "conversion" of the Indian nation within the confines of its spiritual traditions.

Third, since traditions do not have their foundation in doctrines or beliefs, truth predicates do not apply to them. They fall outside of the scope of applicability of the predicates "true" and "false." Gandhi equivocates between different senses of "truth," but where it concerns propositional truth he should be read as making this point: if religions are traditions, then no religion is false. For instance, in 1924, a Muslim correspondent insisted that Gandhi respond to the following question: "You claim that you are a lover, a seeker and a follower of truth. You have said besides that Islam is not a false religion. It is the command of Khuda [God] that every person should embrace Islam. Why then haven't you embraced Islam?" Gandhi's reply is revealing:

It has nowhere been enjoined that everyone should do everything that is not false. Just as I do not consider Islam to be a false religion, so also do I not consider Christianity, Zoroastrianism or Judaism to be false religions. Which religion, then, should I embrace? Moreover, I do not consider Hinduism a false religion either. What, then, should one like me, a seeker of truth, do? (25:221)

For the letter writer, Gandhi's claim that Islam is not a false religion entails that he must embrace it as the one true religion. Gandhi does not follow the same logic: to him, Islam is not a false religion, because no religion is false (not because Islam is the one true religion). Since no religion is false, the best route to follow is to maintain the religion in which one is born: "Hence I cling to my religion, as a child to its mother. But I have no dislike for other religions, as a child has none for other mothers" (ibid.). In other words: "I therefore prefer to retain the label of my forefathers so long as it does not cramp my growth and does not debar me from assimilating all that is good anywhere else" (31:350-351).

Fourth, traditions do not consist only of ancestral practices, but also of action heuristics that instruct the individual on how to become a better human being. Unlike religious doctrines and other beliefs about the world, such heuristics or rules of thumb are not subject to truth claims. They are instructions for action, whose efficacy is always relative to the experience, context (different cultures, communities, families, groups, etc.), and inclinations of the individual in question. In other words, they function like signposts and their efficacy always depends on the specific situation of the individual in question (Balagangadhara 2005a). 
This aspect of traditions as sets of action heuristics allows us to decipher many of Gandhi's claims about religion as self-realization or knowledge of the self (Gandhi 2007:45). It explains why he views religions as moral guidelines, all of which are valid. Since such heuristics are not bearers of truth claims, nothing prevents them from migrating from one tradition to another. Unlike beliefs about the world, they are not restricted by requirements of consistency. Taking into account this characteristic of traditions, Gandhi's suggestion that one religion can assimilate valuable aspects of another religion makes perfect sense. It also explains his stance that a tradition's loss of the capacity to instigate moral or spiritual growth in a community or a human being is synonymous to its death. This would entail that the tradition's action heuristics no longer work for its followers.

We cannot preach such action heuristics and insist that others accept them. Since the efficacy of heuristics depends on a range of things - the experience, background, context (including the group and family within which one is born), and inclinations of the individual - it does not even make sense to persuade anyone of their virtues. The role of such heuristics is to generate certain kinds of action, both internally as modes of reflection and externally as particular attitudes towards oneself and others in the world. Inevitably, then, the best way to express such instructions for action is by embodying the kind of actions and attitudes they generate. The best way to learn such heuristics is not through verbal expression and reproduction but through mimesis of actions and attitudes. ${ }^{19}$ Most often such mimesis occurs in a subliminal way. This accounts for Gandhi's statements on the self-propelling nature of religion and his simile of the rose and its fragrance.

It also allows us to take the next step in decoding his notions of "religion" and "truth." He uses "true" and "false" in a pragmatic sense, rather than in terms of the semantic conception of truth: truth is that which helps an individual to reach his goal. "Truth" refers to the efficacy of action heuristics in enabling the individual to progress in the process of moral and spiritual growth. For this reason, Gandhi keeps emphasizing that all religions have some truth and some error in them; all traditions contain practices and action heuristics that are more or less efficacious. As traditions, religions are essentially human products

19 On the meaning of "setting the example" and its difference from generating principles for all human beings, see Bilgrami 2011:100-101. Explaining Gandhi's notion of exemplarity, he writes: "A truly religious person in this world is someone who has come to live with this level of ahimsa, and, in that ideal of religion, the very idea of principles (or doctrines) is replaced by the idea of exemplarity" (ibid.:101). 
that are transmitted from generation to generation. Consequently, all contain the imperfections that are typical of any human product.

Fifth, many interpreters view the "equality of all religions" as the foundation of Gandhi's reasoning on religious conversion. Often, however, this idea is reduced to a slogan. Taking into account the above hypothesis, how should this notion of equality of religions be understood? If the religious traditions of a people or community are sufficient to meet its needs, what are the implications of the claim that all religions are equal? If Gandhi's statements are taken seriously, it follows that religious traditions are equal in the sense that they meet the needs of particular communities. It is their function to do so. This does not imply, however, that the needs of one community are necessarily equal to the needs of other communities. In that case, the religion that satisfies the need of some particular community could be "more" or "less" than the other, in so far as one can speak in these terms about the needs of people.

Consider again the modifications in the famous example: "Every nation's religion is as good as any other" was replaced by "Every nation considers its own faith to be as good as that of any other." This indicates that Gandhi's point is not that all religions are "equal" or "as good as any other," but that all nations consider their traditions to be so. Functionally, in meeting the needs of a certain people, they are symmetrical. I believe that this is the best way to make sense of utterances like the following: "Accept all religions as equal, for all have the same root and the same laws of growth" (64:203).

Briefly put, Gandhi advocates the functional symmetry between traditions: in their function of providing action heuristics to people and, as such, in fulfilling the needs of a people and a community, traditions are symmetrical. This is very different from saying that all religions are equal. Even though Gandhi often expresses his idea in terms of "equality" or "equal truth," the notion of functional symmetry better captures the message he aims to convey. It is less susceptible to misinterpretation than the idea of equality of religions, since it avoids attributing equal "truth" to all religious doctrines and running into inconsistency.

More, it also avoids the suggestion that Gandhi's claims about "equality" are all about giving "equal respect" to other religions. In 1930, Gandhi rejected the formula of "respect" and introduced "equality of religions" (44:166-167). Hence interpreting his "equality of religions" as equal respect for all religions is ill advised. Similarly, he did not like the word "tolerance" because of its connotation of condescension (Iyer 1973:246). Rather than "respecting" or "tolerating" other religions, Gandhi incites one to study them and learn from them. The notion of functional symmetry helps us understand why: religions are of "equal value" in so far as they provide action heuristics to pursue spiritual and 
moral growth; consequently, adopting such action heuristics from other traditions can enrich one's own tradition.

Finally, this hypothesis allows clarification of Gandhi's antagonism to conversion and explains the incomprehension towards Christian proselytism in India. If "religion" is the tradition or set of ancestral practices that constitute a community, then proselytizing will inevitably be experienced as an unwelcome and disruptive intrusion into the communal life of such traditions. Given that traditions as sets of practices and action heuristics are not bearers of truth predicates, the charge that a tradition is "false religion" and should be replaced by "true religion" becomes incomprehensible. Moreover, such a stance hinders the members of certain traditions from learning from the action heuristics at their disposal. Traditions possess the resources to change and reject harmful practices or heuristics, rather than be replaced as a whole. In fulfilling the needs of a people or community, traditions stand in a relation of functional symmetry. Under these conditions, proselytizing becomes absurd and uncalled for - or a hindrance to spiritual and moral growth. It is because of this, I would like to claim, that conversion in India is often experienced as a violation of the integrity of a community and its tradition.

\section{Conclusion}

During the last six decades, Gandhi has been pushed into the corner of moral sainthood and sometimes he "seems more revered than understood" (Mishra 2007:5). Interest in his writings most often takes the form of fascination with the life of this extraordinary individual. This approach misses the uniqueness of Gandhi's contribution to systematic thinking about humanity and its cultures. I would like to suggest that a range of deep-rooted Indian attitudes and modes of reasoning are reflected in Gandhi's writings. In this article I have aimed to demonstrate that the conceptual distortion in his use of terms such as "conversion," "belief," and "truth" can be systematically studied and explained by theorizing the clusters of common ideas that give shape to this distortion. This provides a new perspective in the interpretation of the writings of Gandhi and other Asian thinkers.

As such, the case of Gandhi remains highly relevant to contemporary debates on religion and conversion. Gandhi's reasoning shows that one cannot brand all opposition to conversion as yet another manifestation of Hindu nationalism ${ }^{20}-$ a tendency that is clearly present in today's debate on reli-

20 Of interest here are Gandhi's conflicts with his contemporary V. D. Savarkar, the Hindu nationalist leader (Neufeldt 2003). 
gious conversion in India. His insights open up a new perspective on today's incomprehension and resentment towards practices of conversion and proselytization in India and elsewhere. His reflections also offer a more promising route towards addressing the anti-conversion sentiment shared by many Indians, without taking the retrograde step of implementing legislation that bans proselytization.

The case of Gandhi shows how Indian culture and its intellectual traditions hold the potential of offering alternative conceptual resources for theory formation in the contemporary study of religion, culture, and politics. For too long, the academic world has assumed that the building of theoretical frameworks in the human and social sciences is somehow the privilege of thinkers from Europe or North America. ${ }^{21}$ The result is that these sciences have often presented the experience of one culture as though it is the universal human experience (Balagangadhara 2012).

\section{References}

Arnold, David. 2001. Gandhi. Harlow: Longman.

Balagangadhara, S. N. 2005a. "How to Speak for the Indian Traditions: An Agenda for the Future." Journal of the American Academy of Religion 73(4):987-1013.

. 2005b. "The Heathen in His Blindness..." Asia, the West, and the Dynamic of Religion, 2nd, rev. ed. New Delhi: Manohar Publishers.

- 2012. Reconceptualizing India Studies. New Delhi: Oxford University Press.

Bilgrami, Akeel. 2001. "Gandhi's Integrity." Raritan: A Quarterly Review 21(2): 48-67.

- 2003. "Gandhi, the Philosopher." Economic and Political Weekly $38(39): 4159-4165$.

. 2011. "Gandhi's Religion and Its Relation to His Politics." In Judith M. Brown

and Anthony Parel (eds.), The Cambridge Companion to Gandhi, Cambridge and

New York: Cambridge University Press, 93-116.

21 Moreover, this is also reflected in the fact that the main production of academic books and articles lies in the West. According to the World Social Science Report 2010: "Over the 1998-2007 decade, North America alone produced more than half of the social science articles registered in the Thomson Reuters SSCI database... Europe comes second, with almost 40 per cent of the world's social science articles published. In terms of citations, the internationalization of social science research in developing countries mainly takes the form of a growing dependence on studies and research produced in Europe and North America. Internationalization thus tends to reinforce the centrality of the North. Another sign of this dependence is linguistic. Over 85 per cent of the social sciences refereed journals covered in the Ulrich database are edited in English" (9). 
Brauer, Jerald C. 1978. "Conversion: From Puritanism to Revivalism." Journal of Religion 58(3):227-248.

Bryant, Darrol and Christopher Lamb, eds. 1999. Religious Conversion: Contemporary Practices and Controversies. London and New York: Cassell.

Buckser, Andrew and Stephen D. Glazier, eds. 2003. The Anthropology of Religious Conversion. Lanham: Rowman and Littlefield.

Caldwell, Patricia. 1983. The Puritan Conversion Narrative: The Beginnings of American Expression. Cambridge: Cambridge University Press.

Chatterjee, Margaret. 1983. Gandhi's Religious Thought. London and Indiana: Macmillan and Notre Dame University Press.

Citron, Bernhard. 1951. New Birth: A Study of the Evangelical Doctrine of Conversion in the Protestant Fathers. Edinburgh: Edinburgh University Press.

Claerhout, Sarah. 2010. “'Losing My Tradition': Conversion, Secularism and Religious Freedom in India." Ph.D. diss, Ghent University,

Claerhout, Sarah and Jakob De Roover. 2008. "Conversion of the World: Proselytization in India and the Universalization of Christianity." In Rosalind I. J. Hackett (ed.), Proselytization Revisited: Rights Talk, Free Markets and Culture Wars, London: Equinox Publishing, 51-76.

Dalton, Dennis. 2012. Mahatma Gandhi: Nonviolent Power in Action, 2nd ed. New York: Columbia University Press.

De Roover, Jakob and Sarah Claerhout. 2010. “The Colonial Construction of What?" In Esther Bloch, Marianne Keppens, and Rajaram Hegde (eds.), Rethinking Religion in India: The Colonial Construction of Hinduism, London and New York: Routledge, 164-183.

De Roover, Jakob, Sarah Claerhout, and S. N. Balagangadhara. 2011. "Secularization and the Problem of Conceptual Migration: The Case of Secularism and Religious Freedom in India." Political Theory 39(5):571-599.

De Roover, Jakob and S. N. Balagangadhara. 2008. "John Locke, Christian Liberty and the Predicament of Liberal Toleration." Political Theory 36(4):523-549.

Dhareshwar, Vivek. 2010. "Politics, Experience and Cognitive Enslavement: Gandhi's Hind Swaraj." Economic and Political Weekly 45(12):51-58.

Dube, Saurabh. 2002. "Conversion to Translation: Colonial Registers of a Vernacular Christianity." South Atlantic Quarterly 101(4):807-837.

Dube, Saurabh and Ishita Banerjee Dube. 2003. "Spectres of Conversion: Transformations of Caste and Sect in India." In Roweena Robinson and Sathianathan Clarke (eds.), Religious Conversion in India: Modes, Motivations, and Meanings, New Delhi: Oxford University Press, 222-254.

Gandhi, Mohandas Karamchand. 1964-1994. The Collected Works of Mahatma Gandhi, 100 vols. Delhi: Ministry of Information and Broadcasting. 
- 2007. An Autobiography or The Story of My Experiments with Truth. London: Penguin Books.

Hackett, I. J. Rosalind, ed. 2008. Proselytization Revisited: Rights Talk, Free Markets and Culture Wars. London: Equinox Publishing.

Harran, Marilyn J. 1983. Luther on Conversion: The Early Years. Ithaca and London: Cornell University Press.

Henderson, David K. 1993. Interpretation and Explanation in the Human Sciences. Albany: State University of New York Press.

Hendrix, Scott. 2004. Recultivating the Vineyard: The Reformation Agendas of Christianization. Louisville, Ky:: Westminster John Knox.

Heredia, Rudolf C. 2007. Changing Gods: Rethinking Conversion in India. New Delhi: Penguin Books.

Iyer, Raghavan, ed. 1973. The Moral and Political Writings of Mahatma Gandhi, vol. 1. Oxford and New York: Oxford University Press.

Jordens, J. F. T. 1987. "Gandhi and Religious Pluralism." In Harold G. Coward (ed.), Modern Indian Responses to Religious Pluralism, Albany: State University of New York Press, 3-18. 1998. Gandhi's Religion: A Homespun Shawl. Basingstoke: Macmillan.

Kim, Sebastian C. H. 2003. In Search of Identity: Debates on Religious Conversion in India. New Delhi: Oxford University Press.

Menon, Kalyani. 2003. "Converted Innocents and Their Trickster Heroes: The Politics of Proselytizing in India." In Andrew Buckser and Stephen D. Glazier (eds.), The Anthropology of Religious Conversion, Oxford: Rowman and Littlefield.

Mishra, Pankaj. 2007. "Foreword to the 2007 edition." In Mahatma Gandhi, An Autobiography or The Story of My Experiments with Truth, London: Penguin Books, $5^{-11 .}$

Morrison, Karl F. 1992. Understanding Conversion. Charlottesville: University Press of Virginia.

Muldoon, James, ed. 1997. Varieties of Religious Conversion in the Middle Ages. Gainesville: University Press of Florida.

Neufeldt, Ronald. 2003. "The Hindu Mahasabha and Gandhi." In Harold G. Coward (ed.), Indian Critiques of Gandhi, Albany, N.Y.: State University of New York, 131-151. Parekh, Bhikhu. 1997. Gandhi. Oxford: Oxford University Press.

Parel, Anthony J. 2000. "Introduction: Gandhian Freedoms and Self-Rule" In Anthony Parel (ed.), Gandhi, Freedom, and Self-rule, Lanham, Md.: Lexington Books, 1-23.

- 2006. Gandhi's Philosophy and the Quest for Harmony. Cambridge: Cambridge University Press.

Parel, Anthony J., ed. 2009. Hind Swaraj and Other Writings, centenary ed. Cambridge: Cambridge University Press. 
Robinson, R. and Sathianathan Clarke, eds. 2003. Religious Conversion in India: Modes, Motivations, and Meanings. New Delhi: Oxford University Press.

Sarkar, Sumit. 2007. "Christian Conversions, Hindutva, and Secularism." In A. Dingwaney Needham and R. Sunder Rajan (eds.), The Crisis of Secularism in India, Durham and London: Duke University Press, 356-367.

Seshagiri Rao, K. L. 1990. Mahatma Gandhi and Comparative Religion, 2nd ed. Delhi: Motilal Banarsidass.

_ 1999. "Conversion: A Hindu/Gandhian Perspective." In Christopher Lamb and M. Darroll Bryant (eds.), Religious Conversion: Contemporary Practices and Controversies, London and New York: Cassell, 136-150.

Singh, Ajai R. and Shakuntala A. Singh. 2004. "Gandhi on Religion, Faith and Conversion: Secular Blueprint Relevant Today." Mens Sana Monographs 2(1-3):79-87.

Skaria, Ajay. 2002. "Gandhi's Politics: Liberalism and the Question of the Ashram." The South Atlantic Quarterly 101(4): 955-986.

—. 2011. "Gandhi's Religion." In Sanjay Dube (ed.), Handbook of Modernity in South Asia: Modern Makeovers, New Delhi: Oxford University Press.

Tidrick, Kathryn. 2006. Gandhi: A Political and Spiritual Life. London: Tauris.

Ustorf, Werner. 2000. "Mission." In Adrian Hastings, Alistair Mason, and Hugh Pyper (eds.), The Oxford Companion to Christian Thought, Oxford: Oxford University Press, 440-442.

Viswanathan, Gauri. 2007. "Literacy and Conversion in the Discourse of Hindu Nationalism." In A. Dingwaney Needham and R. Sunder Rajan (eds.), The Crisis of Secularism in India, Durham and London: Duke University Press, 333-355.

Wicks, Jared. 1992. Luther's Reform: Studies on Conversion and the Church. Mainz am Rhein: von Zabern.

World Social Science Report. 2010. Knowledge Divides: Summary. Paris: United Nations Educational, Scientific and Cultural Organization and International Social Science Council. 